\title{
Determinants of Kosovo Trade: A Gravity Model Approach
}

Florin Peci, Mario Holzner, Enver Kutllovci*

\section{Abstract:}

This study attempts to identify and quantify the factors affecting bilateral trade flows between Kosovo and its trading partner countries using a gravity model. The econometric model is estimated based on both economic and institutional aspects. The results show that family networking with Kosovo emigrants determines to a large extent both exports and imports, while corruption and informality in the partner country seem not to be issues with regard to Kosovo imports. This comes as a surprise given the initial assumption that Kosovo trades more with countries that have a high share of corruption because of informal networks between small and medium enterprises (SME) predominant in Kosovo. The regional CEFTA free trade agreement has a positive effect on both Kosovo imports and exports.

Key words: international trade, gravity model, informality, Kosovo

JEL: F1, P33, E26

DOI: $10.2478 / v 10033-010-0013-4$

\section{Introduction}

This study aims to analyse the determinants of current Kosovo trade flows. We have focused on the role of specific determinants like institutional and regional factors. For this purpose a gravity model was estimated.

The Republic of Kosovo as a developing country is entering a new phase in its history as the newest independent state in the world. Domestic governmental

\section{*Florin Peci}

Customs of Kosovo-Prishtine

E-mail: Florin.Peci@dogana-ks.org

\section{Mario Holzner}

The Vienna Institute for International Economic

Studies (wiiw), Vienna

E-mail: holzner@wiiw.ac.at

\section{Enver Kutllovci}

Faculty of Economics, University of Prishtine

E-mail: ekutllovci@hotmail.com institutions have resumed all the responsibilities from the temporary United Nations Administration Mission in Kosovo (UNMIK). Similar to other states in the Balkans, the Republic of Kosovo wants to continue the process of integration into the European Union.

After the 1999 war in Kosovo the United Nations (UN) established UNMIK', which immediately commenced a liberal policy of trade characterised by simplicity and impartiality intended to stimulate the private sector and provide for better export conditions. However, this trade liberalisation was not accompanied with an improvement in the competitive ability of the local producing sectors, and unfortunately caused a high trade deficit (Riinvest, 2003).

\footnotetext{
${ }^{1}$ UNMIK was established in June 1999 with the promulgation of UNSC Resolution 1244(1999) to carry out administration of all sectors of society, including the economy, in Kosovo until a final settlement is found.
} 
The break-up of the former Yugoslavia had a strong impact on labour markets and migration has changed the labour force. Migration flows out and within the area have become a crucial factor of growth and development in all the countries of the Balkans, especially in Albania and Kosovo. The large outflows of population brought significant changes to socio-economic composition and demographic trends. For instance, in Albania almost 20 percent of the population has left the country since 1989. In Kosovo, it is assumed that approximately 25 per cent of the population is currently living abroad (Riinvest, 2007).

The objective of this study is to find out more about the specific determinants of current Kosovo trade flows in a gravity model context. To our knowledge this has not yet been done, also due to the fact that Kosovo Customs has begun collecting higher quality trade data only recently. Moreover this could provide an informative basis for the development of policy recommendations that could improve the trade balance of Kosovo in a free trade environment.

The study is organised as follows: In part one we will provide a general overview on trade policy and trade developments in Kosovo. Part two will deal with the gravity model methodology used and the specific hypotheses analysed. In part three we will discuss the results of our research. Part four will provide conclusions and policy recommendations.

\section{Trade policy and trade developments in Kosovo}

\subsection{Trade Policy in Kosovo}

In Kosovo, under the general economic policy of UNMIK, unique and specific fiscal and custom policies were created starting with the creation of comprehensive custom and taxation control of imported goods and establishment of a functioning flexible trade regime with the rest of the world. ${ }^{2}$

However, it is evident that the economy of Kosovo after the war in 1999 faced many problems that derive from the sphere of the political and institutional set-up, including a privatization process accompanied by high unemployment rates, excessive import growth, a weak

\footnotetext{
${ }^{2}$ According to UNMIK (1999): 'UNMIK, from the beginning of the mission in Kosovo, was determined on a simple trade regime with a two level customs tax: $10 \%$ in value for all imported goods according to customs tariff, vis-a vis goods that are released from the payment of customs obligation, a 0\% rate. Also since July 1, 2001 this includes the value added tax (VAT) of $15 \%$ on value as well as the excise tax on quantity for specific goods'.
}

export sector and the growth of the budget deficit (Riinvest, 2003). Kosovo is a consumption economy dominated by imports with very low export activity. Current economic activity is mainly conducted by the private sector, which is small in scale. Relatively large inflows of remittances are an important source of income for the economy of Kosovo.

Before 2007, Kosovo had signed FTAs (Free Trade Agreements), with many countries in the region. Afterwards these agreements were substituted by the CEFTA (Central Europe Free Trade Agreement). Kosovo's membership in CEFTA is an important asset for the country, especially with regard to its European integration process. CEFTA rules have been harmonized with the principles of the EU and the WTO. For Kosovo, CEFTA is of paramount importance in improving the competitive position of Kosovo's industries in regional markets and in attracting FDI. In the future process of integration, Kosovo will gear up institutions and policies to comply with the requirements of the WTO. Application for membership to the WTO is a complex process and requires a huge engagement of local institutions. However, membership would ensure full integration into world markets (MTI, 2009).

However, from the beginning of the implementation of CEFTA, the experience of Kosovo so far has not been very positive due to political animosities persisting in the region. UNMIK was a signatory of the CEFTA on behalf of Kosovo (Kosovo's international representation and the negotiating process for bilateral FTA-s and CEFTA were conducted by UNMIK representatives), and Serbia and Bosnia and Herzegovina do not recognize the institutions of the Republic of Kosovo and the documentation issued by them. As a consequence, Kosovo's exports to these countries have been almost at a stand-still for a long time, although there are ongoing efforts to resolve these issues.

It has to be mentioned that the trade policies in Kosovo have been developed in specific circumstances, in a speedy and simple way, by using the Customs of Kosovo as an instrument for realizing the main objective of gathering income for Kosovo's consolidated budget (UNMIK, 2006). However, with the new state the general economic situation has changed. The new circumstances under which Kosovo businesses have developed require the application of new forms of procedures and new general regulations as provided by the basic principles of the WTO. 


\subsection{Kosovo Trade Performance}

Data published by the Statistical Office of Kosovo (SOK) on external trade provide the following picture. In the period 2001-2008, Kosovo had a negative trend in its trade balance, which by the end of 2008 reached $€ 1730$ million (SOK, 2008). In 2008, imports amounted to $€ 1928$ million as a result of higher domestic demand. Based on the 2008 Report of the Central Bank of Kosovo, the trade deficit in Kosovo had reached $43 \%$ of GDP by the year 2008 (CBK, 2008). At the same time, exports in 2008 had reached the value of only $€ 198$ million. In 2008 exports covered imports by only $10 \%$. In the same year exports increased by $20 \%$, while imports increased by as much as $22 \%$.

The composition of the goods exported from Kosovo in 2008 was generally dominated by raw materials and metals which accounted for around 63 percent of general exports. Chemical products, alcoholic beverages and tobacco accounted for around 32 percent of total exports, while livestock, food, fuel, machinery and other transport equipment, and other raw materials in small quantities made up only 5 percent of general exports (CBK, 2008). With regard to imports, in recent years there has been a slight increase in imports of fuel, machinery and other equipment, chemical products, raw materials, food and livestock. The structure of imports in 2008 remains similar to previous years, with mineral products dominated by oil making up 20 percent of the total. The import of food and beverages comprised 13 percent of total imports. The import of base metals comprised 9 percent of total imports, while transport means made up 7 percent of

\begin{tabular}{|c|c|c|c|c|}
\hline Years & Export & Import & $\begin{array}{c}\text { Trade } \\
\text { balance }\end{array}$ & $\begin{array}{c}\text { Import } \\
\text { coverage }\end{array}$ \\
\hline \hline 1 & 2 & 3 & $4=2-3$ & $5=(2 / 3)^{*} 100$ \\
\hline \hline 2001 & 10,559 & 684,500 & $-673,941$ & 1.5 \\
\hline 2002 & 27,599 & 854,758 & $-827,159$ & 3.2 \\
\hline 2003 & 35,621 & 973,265 & $-937,644$ & 3.7 \\
\hline 2004 & 56,567 & $1,063,347$ & $-1,006,780$ & 5.3 \\
\hline 2005 & 56,283 & $1,157,492$ & $-1,101,209$ & 4.9 \\
\hline 2006 & 110,774 & $1,305,879$ & $-1,195,105$ & 8.5 \\
\hline 2007 & 165,112 & $1,576,186$ & $-1,411,074$ & 10.5 \\
\hline 2008 & 198,463 & $1,928,236$ & $-1,729,773$ & 10.3 \\
\hline
\end{tabular}

Source: Statistical Office of Kosovo.

Table 1: External trade flows of Kosovo, in EUR 1,000 total imports; the rest were imports of different goods (CBK, 2008). An increase of imports of capital goods consisting of machinery, tools and equipment used mainly for production, indicates that productive activity in Kosovo is increasing. The economic growth of Kosovo in 2007 of 3.5 percent is rather low when compared with other countries in the region which reached GDP increases of more than 6 percent in 2007 and less than 6 percent in 2008. Kosovo's economy is small, highly open with imports being around $60 \%$ of GDP, and by poor by regional standards with GDP per capita around $\$ 1,448$ per year (MEF, 2007). In Kosovo in 2008 there was a somewhat higher increase of GDP by 5.4 percent (CBK, 2008). Foreign direct investment (FDI) in 2007 made up $€ 114$ million, or approximately 5 percent of GDP (MTI, 2007).

Kosovo exports at the beginning of 2000 mainly targeted countries in the region due to many institutional and managerial insufficiencies, as well as the lack of knowledge and experience of foreign markets among local exporters. Nevertheless, with time, these difficulties have been reduced. Problems do remain, however, particularly with the recognition of the origins of goods of local producers from some countries in the region that are included in the Free Trade Agreement. Problems in this regard have arisen specifically among countries that are members of the Central European Free Trade Agreement (CEFTA). Kosovo exports to CEFTA members in the region in 2008 account for 31 percent, whilst exports to countries that are members of the European Union (EU) comprise 47 percent. The remaining 22 percent of exports go to other countries (CBK, 2008). In 2008 the import of goods from members of the CEFTA comprised 37 percent, imports from the EU accounted for 36 percent, while the remaining 27 percent of imports came from other countries (CBK, 2008).

CEFTA's impact on the growth of trade exchange between Kosovo and the region was partial. The agreement was not equally beneficial for Kosovo when compared to some of its trading partners. For example, Serbia and Bosnia and Herzegovina since 2007 tried to block many of Kosovo's exports, despite having CEFTA membership. Figure 1 shows that 


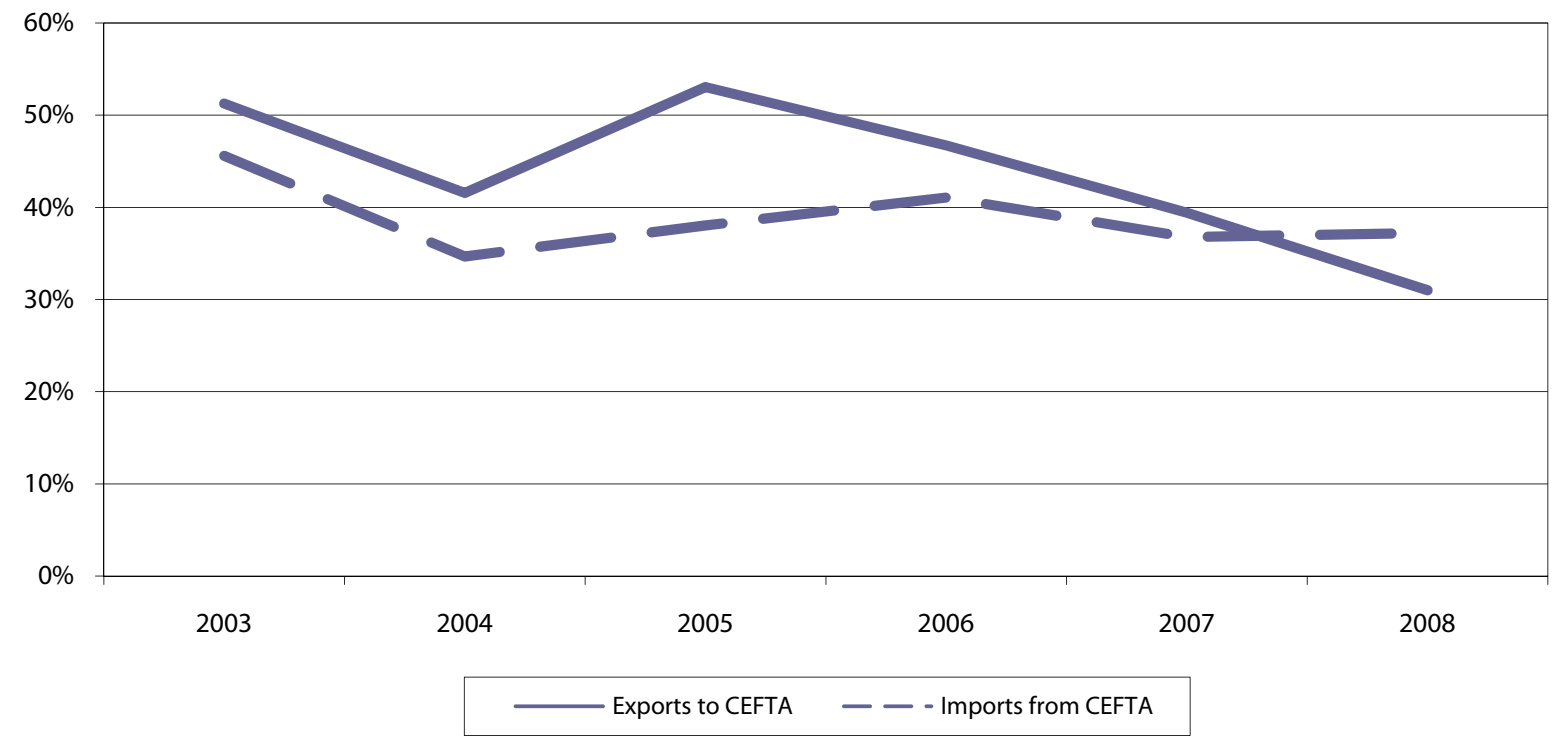

Source: Statistical Office of Kosovo.

Figure 1: Share of Kosovo trade with CEFTA countries, in \% of total (2003-2008)

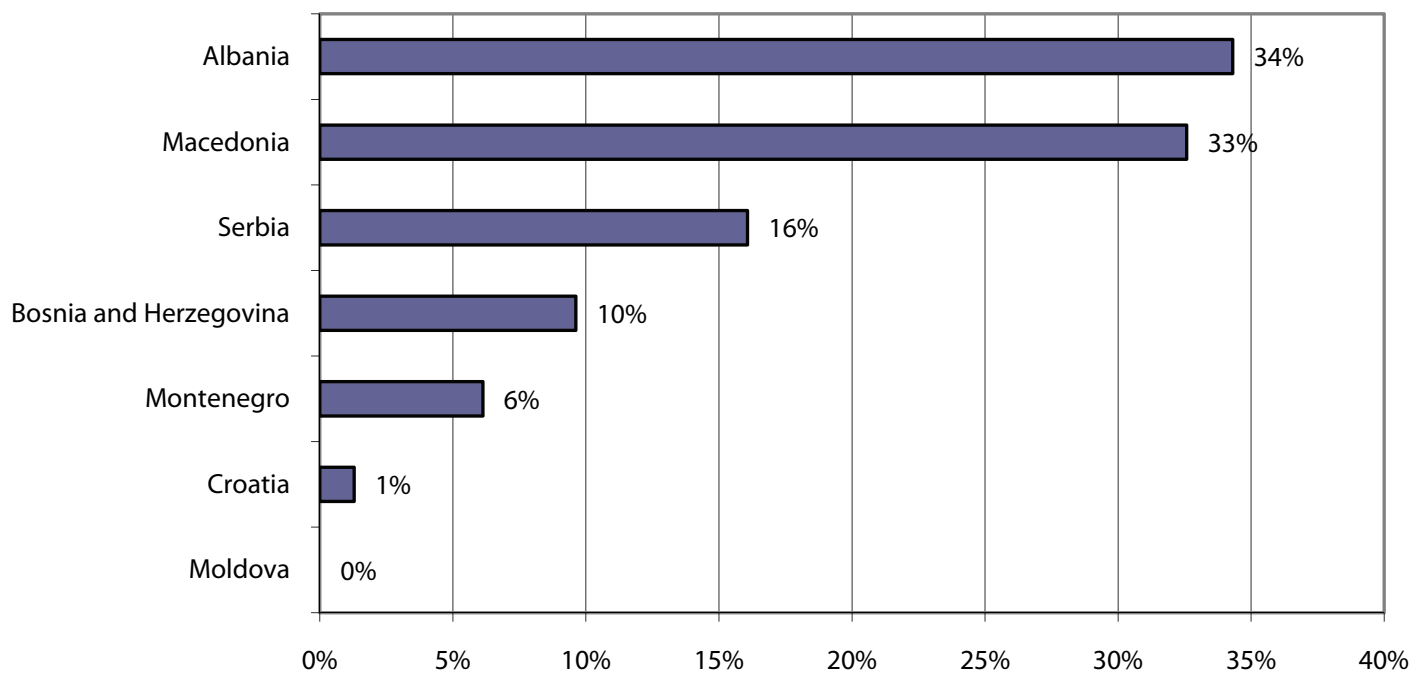

Source: Statistical Office of Kosovo.

Figure 2: Shares of Kosovo exports to CEFTA countries, in \% of total exports to CEFTA, 2008

over the last years the share of Kosovo's exports and imports to other members of CEFTA has been reduced instead of increased.

The main partner among the CEFTA members is Albania, where Kosovo exports more than a third of its overall exports to CEFTA members, about $€ 62$ million in 2008. The second partner is Macedonia, with a bit less than a third, while Serbia, Bosnia and Herzegovina and Montenegro make up for most of the remaining third. Exports to Croatia and Moldova are negligible. On the other hand, the major CEFTA import partners are
Macedonia and Serbia. The imports from these states make up $77 \%$ of all the CEFTA imports, about $€ 718$ million in 2008.

\section{Methodology}

\subsection{The Gravity Model}

Newton's law of gravitation has found applications in the social sciences in the study of human behaviour, and researchers have used gravity models for the empirical 
analysis of bilateral trade flows in international trade. The gravity model of trade suggests that trade flows between two countries are based on the economic size of each country often using Gross Domestic Product (GDP) as a proxy, and the distance between these two units, using e.g. the distance between the countries' capital cities, as a proxy.

This general model applied in international trade analysis has been an empirical success, but theoretical justification is weak. Tinbergen (1962) is one of the earliest authors that used a simple form of the gravity model of bilateral trade in analysing bilateral trade flows. Also, the gravity equation can be analysed as a partial equilibrium model of export supply and import demand (Linnemann, 1966). The gravity approach could be linked with theories of international trade and expanded by showing that this model could be derived from a Ricardian framework (Eaton and Kortum, 1997), applying the Heckscherer-Ohlin model with perfect and imperfect product specialization. Anderson (1979), Bergstrand (1985), Helpman and Krugman (1985), have shown that price terms in addition to the simple gravity equation variables are also statistically significant in explaining trade flows among countries.

Transport costs are a relevant factor of trade if we consider the production of goods in different countries, which is inconsistent with factor price equalization. These transport costs, for which the distance between the two countries serves as a proxy, determine the volume of the trade flow. Several authors concluded that factors like income and distance between countries were statistically significant and had positive and negative signs, respectively (Oguledo and MacPhee, 1994, Karemera et al., 1999). Transport costs for particular goods are determined by the goods' weight, other physical attributes, location, means of transport, distance, as well as other factors. Frankel (1997) argues that factors causing impediments to trade also come from government policies and institutions.

In this line, North (1990) argues that throughout history government institutions have controversially affected the performance of economies. Countries with good institutions tend to trade more and perform better. Such institutions include Free Trade Agreements and membership in customs unions, which are designed to increase international trade, increase economic development, create a favourable business environment, and attract foreign capital. A study on trade among Central and East European countries by De Benedictis, De
Santis and Vicarelli (2005) found evidence that the presence of the Central European Free Trade Agreement (CEFTA) helped to expand intra-regional trade.

Intra-regional trade cooperation in the early 2000s in the West Balkans was initiated by the EU under the Stability Pact as a precondition for creating a network of FTAs in the region. Through CEFTA, participating countries hoped to mobilise efforts to integrate into the EU and other international institutions. Later, under the auspices of the Stability Pact for SEE, the Agreement on Amendment of and Accession to the CEFTA was signed in Bucharest on 19 December 2006. This Agreement replaced all the bilateral agreements previously applied in the region. Full implementation of CEFTA started at the end of 2007. CEFTA envisages an improved mechanism for settlement of disputes that might occur during the agreement implementation, which represents a new quality and a factor of higher security of trade liberalisation in the region. Besides the abovementioned, new areas have been opened for the development of mutual relations with regard to liberalisation of services, investment issues, public procurement, intellectual property, and the possibility for CEFTA cumulation of origin. CEFTA also ensures that mutual trade relations among CEFTA parties should be developed in accordance with WTO rules. This practically implies that even before WTO membership, the systemic setting of the economy should be adjusted to WTO rules, representing a strong factor of predictability and transparency for foreign trading partners, foreign investors and local entrepreneurs.

However, due to weak institutions and late implementation of reforms there are considerable informal trade flows between the SEE countries (see Holzner and Gligorov, 2004). Acemoglu et al. (2001), suggests that institutions that foster the enforcement of property rights, stability, and restrictions on rent seeking behaviour by individuals promote economic activity. It is interesting to note that the results of Duc, Lavallee and Siroen (2008) show that more corrupt countries are generally less trade open, but that two corrupt nations do not necessarily trade less between each other. Thus an informal network effect in trade might exist.

Lately migrant workers' remittances have become an important source of income. In some countries of Southeast Europe, officially recorded remittances take up a sizeable share of more than 10 percent of GDP. Small countries such as Kosovo are highly dependent on remittances as a result of the large portion of their 
population abroad. There are different theories why migrants are likely to remit when they are willing to return to their country of origin. They send remittances so that they can show their intentions to return and to maintain links with their family. This behaviour possibly generates investment from migrants as well as trading (Lucas and Stark, 1985). In fact, remittances support the growing trade deficit in the majority of these countries. Under these macroeconomic circumstances, remittances play an important role by providing complimentary social protection and correcting for limited government policy interventions. In this respect Ghatak et al. (2009) find evidence that migration from Central and East European countries to the UK positively enhances bilateral trade flows.

Similarly, cultural factors and especially common languages are well-known determinants of trade. This is analysed for instance by Malitz (2008), who describes the channels through which a common language promotes bilateral trade.

\subsection{Gravity Model Equations}

In our analysis we seek to verify the following hypotheses, which we developed in accordance with the quoted literature as well as the abovementioned specific features of the Kosovo economy and trade policy:

$\mathbf{H}_{1}$ : Kosovo trades more with large countries measured by GDP.

$\mathbf{H}_{2}$ : Kosovo trades less with distant countries due to high transport costs.

$\mathbf{H}_{3}$ : Kosovo trades more with countries with a large Albanian speaking population (Albania, Macedonia).

$\mathbf{H}_{4}$ : Kosovo trades more with countries with a large Kosovo migrant population (Switzerland, Germany).

$\mathbf{H}_{5}$ : Kosovo trades more with CEFTA countries due to the Free Trade Agreement.

$\mathbf{H}_{6}$ : Kosovo trades more with countries that have a high share of corruption under the assumption of informal networks between small and medium enterprises (SME).

In order to test these hypotheses we employ a gravity model of trade. A gravity model is usually estimated over a pool of countries for a number of years (Deardorff, 1998; Anderson and Van Wincoop, 2003). However, similar to Vujcic and Sosic (2005) we argue that a single country specification best fits the aim of analysing Kosovo trade specifically. Also, the single country gravity model helps us to avoid troubling specification problems that arise in pooled estimates and issues of heterogeneity in countries. However, its main advantage to a full-fledged gravity model is that it allows extracting differences in export and import patterns separately, following e.g. Summary (1989), Depken and Sonora (2005) and Sonora (2008).

The estimated single country gravity model equations for exports and imports are:

$$
\begin{aligned}
& \text { In } X_{i}=a_{0} \quad a_{1} \ln Y_{i} \quad a_{2} \ln D_{i s t_{i}} a_{3} \text { Lang } a_{4} \text { Mig } a_{5} \text { CEFTA } \\
& a_{6} \ln C P I_{i} u_{i(1)} \\
& \ln M_{i}=a_{0} \quad a_{1} \ln Y_{i} \quad a_{2} \ln \text { Dist }_{i} \quad a_{3} \text { Lang } a_{4} \text { Mig } a_{5} \text { CEFTA } \\
& \mathrm{a}_{6} \ln C P I_{i} \mathrm{u}_{\mathrm{i}(2)}
\end{aligned}
$$

Where In denotes natural logarithms, $X i$ denotes the value of exports from Kosovo to country $i, M_{i}$ denotes the value of imports from country $i$ to Kosovo, $a_{0}$ is the intercept, $Y i$ is GDP in the destination/source market. Disti denotes the geographical distance in kilometres between the capitals of Kosovo and country i. Lang is a dummy for countries with a substantial share of the population speaking Albanian ( $=1$ for Albania and Macedonia, 0 otherwise). Mig is a migrant population dummy for Germany and Switzerland ( $=1$, if true, 0 otherwise). The CEFTA dummy variable takes a value of 1 when countries are members of the Central European Free Trade Agreement ( 0 otherwise). $C P I_{i}$ is the Corruption Perception Index, which acts as a proxy for informality in country $i$. Finally, $u i$, is the error term. The data reflect the year 2008. The data on bilateral exports and imports are obtained from the Statistical Office of Kosovo (SOK) as well as from the Customs of Kosovo, and GDP is taken from the IMF's World Economic Outlook (WEO) database. The Corruption Perception Indices are obtained from Transparency International. The distance between capitals was calculated using the 'geod' program, which is part of the 'PROJ' system available from the U.S. Geological Survey.

\section{The Results}

For the estimation of the import and export equation we performed a stepwise estimation procedure with a backward-selection threshold of a $10 \%$ significance level. We started with the full model. The results for the full model can be found in the appendix. Later, all the 
insignificant variables were removed stepwise. In the case of the single country import gravity model, only the Corruption Perception Index variable was removed, while in the case of the export model both, the GDP of the partner countries as well as the dummy for Albanian speaking countries were removed from the model. It is reassuring that the coefficients of the remaining significant variables as well as the quality of fit of the two models hardly change as compared to the full models presented in the Appendix. It is only in the export model that the coefficient for the corruption variable turns significant after the removal of the two most insignificant variables. Thus this result might have to be analysed with some caution.

Tables 2 and 3 present the results of the respective gravity model estimation, with all the coefficients at least significant at the $10 \%$ level. The gravity model that tries to explain Kosovo imports from its trading partner countries is based on a sample of 122 observations and has an $\mathrm{R}^{2}$ of $68 \%$. Due to heteroskedasticity it was estimated in a robust way. The partner countries' GDP and the trading distance variables show significant coefficients with the expected signs. In addition we find the coefficients for the dummies of countries with a significant Kosovar migration population as well as of countries that are members of the CEFTA free trade area being positive and significant. In fact the CEFTA coefficient is by far the largest one. Finally the dummy variable of Albanian speaking countries has a positive coefficient, however, only at the $10 \%$ significance level.

The export model is estimated on a smaller sample of 48 observations due to the fact that Kosovo exports to only a small number of countries. The quality of the model's fit is at an $\mathrm{R}^{2}$ of $59 \%$. In the export model we find from the traditional gravity model variables only distance to be significant. GDP of the partner country was dropped. It seems that in terms of Kosovo exports, the economic mass of the partner country is not important. The single biggest coefficient is that of countries with large emigrant populations from Kosovo. Also the CEFTA

\section{Stepwise, single country, gravity model of Kosovo imports}

\begin{tabular}{lrrrrrr} 
& Coef. & Std. Err. & $\mathrm{t}$ & \multicolumn{2}{c}{$\mathrm{P}>\mathrm{t}$} & \multicolumn{2}{r}{ [95\% Conf. Interval] } \\
GDP & & & & & & \\
Distance & 1.02 & 0.09 & 11.90 & 0.000 & 0.85 & 1.18 \\
Albanian & -1.05 & 0.18 & -5.76 & 0.000 & -1.42 & -0.69 \\
Migration & 1.54 & 0.88 & 1.75 & 0.083 & -0.21 & 3.29 \\
CEFTA & 1.49 & 0.38 & 3.88 & 0.000 & 0.73 & 2.25 \\
& 2.75 & 0.93 & 2.97 & 0.004 & 0.91 & 4.58 \\
Constant & & & & & & \\
& 17.14 & 1.67 & 10.28 & 0.000 & 13.84 & 20.44
\end{tabular}

No. of obs.

Source: Own calculations.

Table 2

\section{Stepwise, single country, gravity model of Kosovo exports}

\begin{tabular}{lrrrrrr} 
& Coef. & Std. Err. & $\mathrm{t}$ & \multicolumn{2}{c}{$\mathrm{P}>\mathrm{t}$} & \multicolumn{2}{l}{ [95\% Conf. Interval] } \\
& & & & & & \\
Distance & -1.19 & 0.33 & -3.67 & 0.001 & -1.85 & -0.54 \\
Migration & 3.50 & 1.51 & 2.32 & 0.025 & 0.45 & 6.55 \\
CEFTA & 2.53 & 1.18 & 2.14 & 0.038 & 0.15 & 4.91 \\
Less corrupt & 1.41 & 0.66 & 2.12 & 0.039 & 0.07 & 2.74 \\
& & & & & & \\
Constant & 17.48 & 2.85 & 6.14 & 0.000 & 11.73 & 23.22 \\
& & & & & & \\
No. of obs. & 48 & & & & & \\
R-squared & 0.5875 & & & & &
\end{tabular}


dummy is significant and positive. In this regression also the coefficient of the Corruption Perception Index is positive and significant. The interpretation is that Kosovo is exporting more to less corrupt countries than otherwise. This comes as a surprise given the initial assumption that Kosovo trades more with countries that have a high share of corruption because of informal networks between small and medium enterprises (SME) predominant in Kosovo. However, our result was confirmed by a recent study on trade and corruption for African economies by Musila and Sigue (2010) that supports the view that corruption adversely affects international trade.

\section{Conclusions and policy recommendations}

This paper uses a single country gravity model to estimate Kosovo's external trade in terms of imports and exports. While distance appears to be obviously a hindering factor for both exports and imports, a large GDP on the part of the trading partner country is only important in the case of imports. It seems that so far Kosovo exporters were not able to target economically important markets with their products. Family ties with Kosovo emigrants determine to a large extent both exports and imports. It is interesting to note that Kosovo exports more to less corrupt countries. At the same time, corruption and informality in the partner country seems not to be at all an issue with regard to Kosovo imports. Thus it appears that Kosovo traders of legal products are not necessarily involved in international networks of informality. Official trade emerges preferably with countries having low levels of informality. However this might be different for illegal products as well as hidden trade flows. Certainly it is reassuring that Kosovo's membership in the CEFTA yields higher trade shares with member countries. Thus further trade integration, especially with respect to the European Union, might have the positive effect of increasing trade flows.

Given that neither the partner country's GDP nor the Albanian language dummy were significant in the Kosovo exports model the following major policy recommendations can be formulated. Exporting to economically large countries often requires the ability to produce large quantities of tradable goods. In order to exploit gains from international trade, Kosovo economic policy should support local businesses in specialisation and the development of economies of scale. Also, the untapped potential of exporting to neighbouring countries where a large number of population shares a common language should be tackled. $[$.

\section{References}

Acemoglu, D., Johnson, S. and Robinson, J.A. 2001. The colonial Origins of Comparative Development : An Emprical Investigation. American Economic Review 91: 1369-1401.

Anderson, J. 1979. A theoretical Foundation for the gravity

Equation. The American Economic Review 69 (1): 106-116.

Anderson, J. and Van Wincoop, E. 2003. Gravity with gravitas: A solution to the border puzzle. American Economic Review 93(1): 170-192. Bergstrand, J. 1985. The Gravity Equation in International Trade:Some Microeconomic Foundations and Emipirical Evidence. The Review of Economics and Statistics 67: 474-81.

CBK. 2008. Annual Report. Central Bank of the Republic of Kosovo. Prishtine.

Deardorff, A. 1998. Determinants of Bilateral Trade: Does Gravity Work In a Neoclassical World? In: Frankel, J.A. (ed.) The Regionalization of the World Economy, NBER, Cambridge, MA.

De Benedictis, L., De Santis, R. and Vicarelli, C. 2005. Hub-and-Spoke or Else? Free Trade Agreements in the Enlarged European Union.

European Journal of Comparative Economics 2 (2): 245-260.

Depken, C.A. and Sonora, R.J. 2005. Asymmetric Effects of Economic Freedom on International Trade Flows. International Journal of Business and Economics 4(2): 141-155.

Duc, C., Lavallee, E. and Siroen, J.-M. 2008. The Gravity of Institutions. Economie Internationale 113: 95-113.

Eaton, J. and Kortum, S. 1997. Technology and Bilateral Trade. NBER Working Paper No. 6253

Frankel, J. A. 1997. Regional Trading Blocs in the World Economic

System. Institute for International Economics, Washington DC.

Ghatak, S., Pop, S., Monica, I. and Daly, V. 2009. Trade and Migration

Flows between Some CEE Countries and the UK. Journal of International

Trade and Economic Development. 18 (1): 61-78. Helpman, E. and Krugman P. 1985. Market Structure and Foreign

Trade. MIT Press.

Holzner, M. and Gligorov, V. 2004. Illegal trade In South East Europe. European Balkan Observer 2(3): 12-15.

Karemera, D., Smith, I. W., Ojah, K., and Cole, A. J. 1999. A Gravity

Model Analysis of the Benefits of Economic Integration in the Pacific

Rim. Journal of Economic Integration. 14(3): 347-367.

Linnemann, H. 1966. An Econometric Study of International Trade

Flows. North-Holland, Amsterdam.

Lucas, R. E. B. and Stark, O. 1985. Motivations to Remit: Evidence

from Botswana. The Journal of Political Economy 93(5): 901-918.

Malitz, J. 2008. Language and Foreign Trade. European Economic Review. 52(4): 667-699.

MEF. 2007. SemiannualMacroeconomicBulletint. Ministry of Finance and Economy. Prishtine.

MTI. 2007. Kosovo SME Observatory. Ministry of Trade and Industry . Prishtine.

MTI. 2009. Trade Policy of Kosovo. Ministry of Trade and Industry. Prishtine.

Musila, J.W. and Sigue, S.P. 2010. Corruption and International Trade: An Empirical Investigation of African Countries. World Economy 33(1): 129-146.

North, D. 1990. Institutions, Institutional Changes and Economic Development. Cambridge University Press: New York. 
Oguledo, V. I. and MacPhee, C. R. 1994. Gravity Models: A Reformulation and an Application to Discriminatory Trade Arrangements. Applied Economics 26(2): 107-120.

Riinvest. 2003. Trade Policy and Export Promotion in Kosovo. Prishtine.

Riinvest. 2007. Diaspora and Migration Policies in Kosovo. Prishtine. SOK. 2008. Statistics of External Trade. Statistical Office of Kosovo. Prishtine.

Sonora, R.J. 2008. On the Impacts of Economic Freedom on International Trade Flows: Asymmetries and Freedom Components. EFZG Working Paper No.08-05.

Summary, R.M. 1989. A Political-Economic Model of U.S. Bilateral Trade. The Review of Economics and Statistics 71(1): 179-182.

Tinbergen, J. 1962. Shaping the World Economy: Suggestions for an International Economic Policy. The Twentieth Century Fund, New York.
UNMIK. 1999. UNMIK Regulation 1999/3. UNMIK Press Release, Prishtine.

UNMIK. 2006. UNMIK's Impact on the Kosovo Economy. Kosovo Economic Outlook, Prishtine.

Vujcic, B. and Sosic, V. 2005. Trade integration and Croatian accession to the European Union. In: Katarina Ott (ed.). 2005. Croatian Accession to the European Union: Facing the Challenges of Negotiations. Books on Croatian accession to the European Union, Institute of Public Finance, Volume 3, Number 3, May..

\section{Appendix}

\section{Single country, full gravity model of Kosovo imports}

\begin{tabular}{lrrrrrr} 
& Coef. & Std. Err. & $\mathrm{t}$ & \multicolumn{2}{c}{$\mathrm{P}>\mathrm{t}$} & \multicolumn{2}{l}{ [95\% Conf. Interval] } \\
& & & & & & \\
GDP & 1.01 & 0.09 & 10.82 & 0.000 & 0.82 & 1.19 \\
Distance & -1.05 & 0.18 & -5.80 & 0.000 & -1.41 & -0.69 \\
Albanian & 1.54 & 0.89 & 1.74 & 0.085 & -0.22 & 3.29 \\
Migration & 1.44 & 0.40 & 3.57 & 0.001 & 0.64 & 2.24 \\
CEFTA & 2.76 & 0.93 & 2.97 & 0.004 & 0.92 & 4.60 \\
Less corrupt & 0.11 & 0.36 & 0.30 & 0.766 & -0.61 & 0.82 \\
& & & & & & \\
Constant & 17.00 & 1.66 & 10.24 & 0.000 & 13.71 & 20.28
\end{tabular}

\begin{tabular}{lr} 
No. of obs. & 122 \\
R-squared & 0.6793 \\
\hline Source: Own calculations. & \\
Table A1 &
\end{tabular}

Single country, full gravity model of Kosovo exports

\begin{tabular}{lrrrrrr} 
& Coef. & Std. Err. & $\mathrm{t}$ & \multicolumn{2}{c}{$\mathrm{P}>\mathrm{t}$} & \multicolumn{2}{c}{ [95\% Conf. Interval] } \\
& & & & & & \\
GDP & 0.16 & 0.22 & 0.72 & 0.473 & -0.28 & 0.60 \\
Distance & -1.14 & 0.34 & -3.40 & 0.001 & -1.82 & -0.47 \\
Albanian & 0.95 & 1.79 & 0.53 & 0.600 & -2.68 & 4.57 \\
Migration & 3.39 & 1.54 & 2.20 & 0.033 & 0.28 & 6.51 \\
CEFTA & 2.61 & 1.35 & 1.93 & 0.060 & -0.12 & 5.34 \\
Less corrupt & 1.11 & 0.79 & 1.40 & 0.170 & -0.49 & 2.71 \\
& & & & & & \\
Constant & 16.73 & 3.02 & 5.54 & 0.000 & 10.63 & 22.83
\end{tabular}

No. of obs.

Source: Own calculations.

Table A2 